\title{
UPAYA GURU DALAM PENGENALAN MEMBACA PERMULAAN ANAK USIA DINI (AUD) DENGAN MENGGUNAKAN MEDIA GAMBAR BINATANG KELOMPOK B DI TK MA'ARUF DESA LANCI JAYA KEC. MANGGELEWA KAB. DOMPU
}

\author{
Jaenab, Srijamilah \\ Mahasiswa Institut Agama Islam (IAI) Muhammadiyah Bima \\ Email: Jaenab@gmail.com
}

\section{ABSTRAK}

Masalah yang diteliti dalam skripsi ini adalag tentang upaya guru dalam pengenalanmembacapermulaananakusiadini(AUD) denganmenggunakan media gambar binatang kelompok B di TK Ma'aruf Desa Lanci Jaya Kec. Manggelewa Kab. Bima. Tujuan penelitian adalah untuk mengetahui upaya guru serta kendala dalam pengenalan membaca permulaan anak usia dini (AUD). Penelitian ini menggunakan metode penelitian kualitatif deskriptif. Subjek penelitian adalah kepala sekolah dan guru. Adapun hasil penelitian ini, bahwa; (1) Upaya Guru Dalam Pengenalan Membaca Permulaan Anak Usia Dini (AUD) di TK Ma'aruf Desa Lanci Jaya Kab. Dompu yaitu; (a) dilakukan dengan menggunakan media gambar binatang, seperti kuda, sapi, kerbau, harimau, laba-laba dan kucing, (b) Menggunakan media Kartu Kata Bergambar, (2) Kendala yang dihadapi oleh Guru Dalam Pengenalan Membaca Permulaan Anak Usia Dini (AUD) di TK Ma;aruf Desa Lanci Jaya Kab. Dompu,antara lain; (a) Ketidakmampuan anak usia dini dalam mengenal huruf alfabetis, (b) Masih banyak anak yang kurang lancar membaca, (c) Karena kurangnya kesadaran atau peran orang tua dalam pengenalan membaca permulaan sejak dalam lingkungan keluarga.

Kata Kunci : Pengenalan Membaca, Anak Usia Dini, Media Gambar Binatang

\section{PENDAHULUAN}

Pendidikan adalah usaha sadar dan terencana untuk mewujudkan suasana belajar dan proses pembelajaran agar peserta didik secara aktif mengembangkan potensi dirinya untuk memiliki kekuatan spiritual keagamaan, pengendalian diri, kepribadian, kecerdasan, akhlak mulia,

Jurnal Pelang̉i Jurnal pemikiran dan penelitian pendidkan Islam anak Usia Dini 
serta keterampilan yang diperlukan dirinya, masyarakat, bangsa dan negara. ${ }^{1}$

Pendidikan Anak Usia Dini adalah suatu upaya pembinaan yang ditujukan kepada anak sejak lahir sampai dengan usia enam tahun yang dilakukan melalui pemberian rangsangan pendidikan untuk membantu pertumbuhan dan perkembangan anak baik pada aspek jasmani dan ruhani agar anak memiliki kesiapan dalam memasuki pendidikan lebih lanjut. $^{2}$

Pendidikan merupakan usaha agar manusia dapat mengembangkan potensi dirinya melalui proses pembelajaran dan atau cara lain yang dikenal dan diakui oleh masyarakat. Undang-Undang Dasar Negara Republik Indonesia Tahun 1945 Pasal 31 Ayat (1) menyebutkan bahwa setiap warga berhak mendapat pendidikan, dan ayat (3) menegaskan bahwa pemerintah mengusahakan dan menyelenggarakan satu sistem pendidikan nasional yang meningkatkan keimanan dan ketaqwaan serta akhlaq mulia dalam rangka mencerdaskan kehidupan bangsa yang diatur dengan undang-undang. ${ }^{3}$ Untuk itu, seluruh komponen bangsa wajib mencerdaskan bangsa yang merupakan salah satu tujuan Negara Indonesia.

Pendidikan anak usia dini, adalah anak yang berada pada usia 0-6 tahun. Anak yang berusia 0-6 tahun yang sedang dalam tahap pertumbuhan dan perkembangan, baik fisik maupun mental. Masa anak usia dini sering disebut dengan istilah "Golden age" atau masa emas. ${ }^{4}$

Pembelajaran pendidikan TK bertujuan membantu meletakkan dasar kearah perkembangan sikap pengetahuan, keterampilan, daya cipta dan menyiapkan anak untuk memasuki pendidikan dasar dengan mengembangkan nilai-nilai agama (moral), fisik motorik, kognitif, bahasa, sosial emosi, dan seni. ${ }^{5}$

Bahasa sebagai salah satu aspek perkembangan yang harus dikembangkan pada usia TK merupakan media komunikasi agar anak

${ }^{1}$ Mansur, Pendidikan Anak Usia Dini dalam Islam, Cetakan Ke-V, (Pustaka Pelajar:Yogyakarta,2014), hal.28.

${ }^{2}$ Fakhruddin, Sukses Menjadi Guru TK-PAUD, Tips, Strategi, dan Panduan Pengembangan Praktisnya, (Jogjakarta:Being, 2010), hal.27

${ }^{3} \mathrm{Ibid}, \ldots \ldots$. hal.38

${ }^{4}$ Suyadi,Manajemen Pendidikan Anak Usia Dini, (Pustaka Pelajar: Yogyakarta, 2011), hal.68.

${ }^{5}$ Solehan, Pendidikan Bahasa Indonesia di SD. (Jakarta: Universitas Terbuka,2008), hal.94. 
dapat menjadi bagian dari kelompok sosialnya. Bahasa dapat berbentuk lisan, gambar, tulisan, isyarat, dan bilangan. Membaca merupakan bagian dari perkembangan bahasa dapat diartikan menterjemahkan simbol atau gambar kedalam suara yang dikombinasikan dengan katakata, kata-kata disusun agar orang lain dapat memahaminya. Anak yang menyukai gambar, huruf, buku cerita dari sejak awal perkembangannya akan mempunyai keinginan membaca lebih besar karena mereka tahu bahwa membaca memberikan informasi baru dan menyenangkan. ${ }^{6}$

Empat aspek keterampilan bahasa yang mencakup dalam pernbelajaran bahasa Indonesia,adalah (1) Keterampilan menyimak, (2) Keterampilan berbicara, (3) Keterampilan membaca, (4) Keterampilan menulis. ${ }^{7}$ Stimulasi yang diberikan oleh guru merupakan hal yang sangat penting dalam meningkatkan kemampuan membaca permulaan anak usia dini. Selain meningkatkan kemampuan membaca permulaan, guru memiliki tugas dan tanggung jawab yang sangat urgen, yaitu menyampaikan akidah dan keimanan yang mampu menghidupkan hati dan mendekatakan manusia dengan Allah dan menyampaikan ilmu pengetahuan.

Pendidikan anak adalah proses mendidik, mengasuh, dan melatih jasmani dan rohani mereka yang dilakukan orang tua sebagai tanggung jawabnya terhadap anak dengan berlandaskan nilai baik dan terpuji bersumber dari Al-Qur'an dan Sunnah. Bahkan dalam Islam sistem pendidikan keluarga ini dipandang sebagai penentu masa depan anak. Sampai-sampai di ibaratkan bahwa surga neraka anak tergantung terhadap orang tuanya. Maksudnya adalah untuk melahirkan anak yang menjadi generasi insan yang rabbani yang beriman, bertaqwa, dan beramal shaleh adalah tanggungjawab guru dan orang tua.

Orangtua dalam hal ini keluarga. Keluarga memiliki peranan yang utama dalam mendidik anaknya sejak dini. Tentu pendidikan yang disampaikan oleeh orang tua dalam rumah tangga adalah pendidikan yang sesuai dengan kebutuhan belajar, terutama proses pengenalan membaca permulaan, dikenalkan oleh orang tua dalam kehidupan keluarga, karena dilingungan keluargaa anak mendapatkan pendidikan

${ }^{6} \mathrm{Ibid}, \ldots . . . . \mathrm{hal} .101$

${ }^{7}$ Farida Rahim, Pengajaran Membaca di Sekolah Dasar, (Jakarta: Bumi Aksara,2011), hal.2

Jurnal Pelang̉i Jurnal pemikiran dan penelitian pendidkan Islam anak Usia Dini 
yang utama.

Dalam pembelajaran membaca permulaan, guru dapat melakukan simulasi pembelajaran dengan menggunakan media gambar. Dalam pembelajaran membaca permulaan guru dapat menggunakan strategi bermain dengan memanfaatkan media gambar. Gambar-gambar tersebut digunakan sebagai media dalam permainan menemukan kata. Siswa diajak bermain dengan menyusun huruf-huruf menjadi sebuah kata yang berdasarkan teka-teki atau soal-soal yang dibuat oleh guru. Titik berat latihan menyusun huruf ini adalah keterampilan mengeja suatu kata.

Membaca merupakan interpretasi yang bermakna darisimbolverbal yang tertulis atau tercetak. Membaca adalah tindakan menyesuaikan arti kata dengan simbol-simbol verbal yang tertulis. Membaca adalah ketrampilan mengenal dan memahami tulisan dalam bentuk urutan lambang-lambang grafis dan perubahannya menjadi wicara bermakna dalam bentuk pemahaman diam-diam atau pengajaran keras- keras. Kegiatan membaca dapat bersuara, dapat pula tidak bersuara Jadi membaca pada hakekatnya adalah kegiatan fisik dan mental untuk menemukan makna dan tulisan. ${ }^{8}$

Adapun istrumen yang digunakan oleh guru dalam meningkatkan kemampuan membaca permulaan, salah satu adalah dengan menggunakan gambar. Gambar adalah tiruan barang (orang, binatang, tumbuhan dan sebagainya) yang dibuat dengan coretan pensil dan sebagainya, pada kertas dan sebagainya. mengungkapkan bahwa gambar adalah alat yang penting bagi pengajaran dan pendidikan. Berdasarkan pendapat-pendapat di atas dapat disimpulkan bahwa gambar sebagai media pendidikan dapat membuat anak untuk melatih dan mempertajam imajinasi anak, maka akan semakin berkembang sudut pandang anak dalam membahasakan gambar. Gambar seri adalah gambar yang urutanya secara seri yang bisa disesuaikan atau diurutkan sesuai dengan urutan jalan ceritanya. ${ }^{9}$

Berdasarkan hasil oberservasi yang dilakukan oleh peneliti tentang pengenalan membaca permulaan pada anak usia dini dengan

\footnotetext{
${ }^{8}$ Basyirudin Usman dan Asnawir, Media Pembelajaran, (Jakarta, Ciputat Pers,2002), hal.45 ${ }^{9} \mathrm{Ibid}, . . . .$. hal.67.
} 
menggunakan media gambar binatang di TK Ma'aruf Desa Lanci Jaya Kab. Dompu, dapat dideskripsikan bahwa anak usia dini masih rendah minat membacanya, hal ini dipengaruhi oleh beberapa faktor, salah satunya adalah media pembelajaran artinya siswa tersebut belum memiliki kemampuan sesuai dengan yang diharapkan, hal tersebut disebabkan karena anak dalam pembelajaran membaca anak kurang dalam mengenal dan memahami huruf.

Melihat rendahnya minat membaca permulaan anak usia dini, maka salah satu cara untuk memudahkan anak belajar lancar membaca adalah dengan menerapkan metode pembelajaran yang sesuai dengan kebutuhan anak. Anak membutuhkan metode yang menarik dalam belajar membaca. Salah satu media yang dugunakan adalah media gambar binatang. Metode ini dapat dinyatakan berhasil apabila menggunakan media yang efektif.

Media gambar binatang dinilai penting karena menjadi alat bantu dalam membentuk untuk meningkatkan kemampuan membaca permulaan bagi anak usia dini dengan menggunakan media gambar. Dengan media gambar anak dapat menyusun kalimat sederhana. Anak mulai senang mendengarkan cerita sederhana dan mulai banyak bercakapcakap, banyak bertanya seperti apa, mengapa, bagaimana, juga dapat mengenal tulisan sederhana. Disatu isi, Alat bantu ini berguna meningkatkan minat belajar anak. Penggunaan media atau alat pembelajaran akan memberikan variasi dalam proses pembelajaran sehingga anak tidak bosan, ada kemauan untuk belajar membaca serta ada peningkatan kemampuan membaca.

Berdasarkan masalah di atas, maka peneliti tertarik melakukan penelitian dengan mengangkat judul "Upaya Guru Dalam Pengenalan Membaca Permulaan Pada Anak Usia Dini (AUD) Dengan Menggunakan Media Gambar Binatang di TK Ma'aruf Desa Lanci Jaya Kab. Dompu".

\section{TINJAUAN UPAYA GURU}

\section{Pengertian Guru}

Guru adalah orang yang memberikan ilmu pengetahuan kepada anak didiknya. Guru dalam pandangan masyarakat adalah orang yang 
melaksanakan pendidikan formal tetapi bisa juga di lembaga pendidikan nonformal seperti mesjid, surau, dirumah dan sebagainnya. ${ }^{10}$

Guru adalah tenaga pendidik yang tugas utamanya mengajar, dalam arti mengembangkan ranah cipta, rasa, dan karsa siswa sebagai implementasi konsep ideal mendidik. ${ }^{11}$

Berdasarkan definis diatas, maka dapat disimpulkan bahwa; peranan guru adalah orang yang telah memiliki Ilmu pengetahuan sehingga dapat mendidik orang lain baik secara formal maupun informal untuk melaksanakan tugas pendidikan yaitu pengajar, membimbing, dan membina peserta didik.

\section{Peranan dan Tanggung Jawab Guru}

Peranan guru hanya mendidik dan mengajar saja. Terkadang banyak guru yang tak mengerti, bahwa mengajar itu adalah mendidik juga. kebanyakan guru sudah mengalami kekeliruan besar dengan mengatakan bahwa tugas itu guru hanya mengajar saja.

Adapun peran serta tanggung jawab guru sesungguhnya sangat luas, meliputi:

a. Guru sebagai pengajar (teacher as instructor),

b. Guru sebagai pembimbing (teacher as counsellor),

c. Guru sebagai ilmuwan (teacher as scientist), dan

d. Guru sebagai pribadi (teacher as person). ${ }^{12}$

Bahkan dalam arti yang lebih luas, dimana sekolah merupakan juga berfungsi sebagai penghubung antara ilmu dan teknologi dengan masyarakat, di mana sekolah merupakan lembaga yang turut mengemban tugas memodemisasi masyarakat dan di mana sekolah turut serta secara aktif dalam pembangunan. Maka dengan demikian peranan guru menjadi lebih luas, meliputi juga:

a. Guru sebagai penghubung (teacher as communicator),

b. Guru sebagai modemisator, dan

c. Guru sebagai pembangun (teacher as contractor).

\footnotetext{
${ }^{10}$ Majid dan Puspitasari, Pendidikan Agama Islam Berbasis Kompeten, (Bandung:PT Rosdakarya, 2006), hal.21.

${ }^{11}$ Muhibin Syah, Psikologi Pendidikan Dengan Pendekatan Baru, (Bandung:PT Remaja Rodakarya, 2015), hal. 256

${ }^{12}$ Hamalik, Proses Belajar Mengajar, (Jakarta: PT Bumi Aksara: 2010), hal.123.
} 
Peranan-peranan tersebut akan kita tinjau satu per satu di bawah ini; ${ }^{13}$

\section{Guru Sebagai Pengajar}

Guru bertugas memberikan pengajaran di dalam sekolah (kelas). Ia menyampaikan pelajaran agar murid memahami dengan baik semua pengetahuan yang telah disampaikan itu. Selain dari itu ia juga berusaha agar terjadi perubahan sikap, keterampilan, kebiasaan, hubungan sosial, apresiasi, dan sebagainya melalui pengajaran yang diberikannya.Untuk mencapai tujuan-tujuan itu maka guru perlu memahami sedalamdalamnya pengetahuan yang akan menjadi tanggung jawabnya dan menguasai dengan baik metode dan teknik mengajar.

Dalam Islam, guru merupakan pewaris keilmuan untuk mengajarkan peserta didik, agar peserta didik dapat menghayati penciptaan langit dan bumi serta beriman kepada Allah SWT. Karakteristik orang yang berilmu salah satunya adalah takut kepada Allah SWT. Sebagaimana firman Allah SWT dibawah ini;

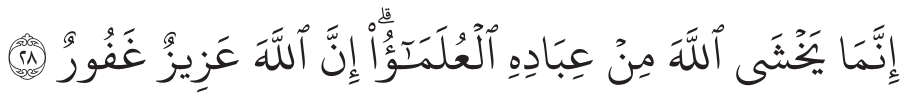

Artinya: Sesungguhnya yang takut kepada Allah diantara hamba-hambaNya, hanyalah ulama, Allah maha pengampung lagi maha pengayang.(Q.S: 82). ${ }^{14}$

Guru harus memiliki karakteristik Ilmu pengetahuan yang benar dalam mengajar dan ilmu tersebut digunakan untuk menolong yang lemah dan berpihak kepada kebenaran serta dijadikan untuk takut dan tunduk kepada Allah SWT. ${ }^{15}$

\section{Guru Sebagai Pembimbing}

Guru berkewajiban memberikan bantuan kepada murid agar mereka mampu menemukan masalahnya sendiri, memecahkan masalalima sendiri, mengenal diri sendiri, dan menyesuaikan diri dengan lingkungnnya. Murid-murid membutuhkan bantuan gum

13

14

${ }^{15} \mathrm{Ibid}, \ldots . . .$. hal.124-126

Jurnal Pelang̉i Jurnal pemikiran dan penelitian pendidkan Islam anak Usia Dini 
dalam hal mengalami kesulitan-kesulitan pribadi, kesulitan pendidikan, kesulitan memililt pekerjaan, kesulitan dalam hubungan sosial, dan interpersonal. ${ }^{16}$

\section{Guru Sebagai Pemimpin}

Sekolah dan kelas adalah suatu organisasi, di mana murid adalah sebagai pemimpinnya. Guru berkewajiban mengadakan supervisi atas kegiatan belajar murid, membuat rencana pengajaran bagi kelasnya, mengadakan manajemen belajar sebaik-baiknya, melakukan manajemen kelas, mengatur disiplin kelas secara demokratis. Dengan kegiatan manajemen ini guru ingin menciptakan lingkungan belajar yang serasi, menyenangkan, dan merangsang dorongan belajar para anggota kelas.

\section{Guru Sebagai Ilmuwan}

Guru dipandang sebagai orang yang paling berpengetahuan. Dia bukan saja berkewajiban menyampaikan pengetahuan yang dimilikinya kepada murid, tetapi juga berkewajiban mengembangkan pengetahuan dan terus-menerus memupuk pengetahuan yang telah dimilikinya.

\section{TINJAUAN TENTANG PENGENALAN MEMBACA PERMULAAN}

\section{Pengertian Membaca Permulaan}

Masa peka anak untuk belajar membaca dan berhitung berada di usia 4-5 tahun, karena di usia ini anak lebih mudah membaca dan mengerti angka. ${ }^{17}$ Anak sebaiknya melai belajar membaca di usia 1-5 tahun karena pada masa ini otak anak akan dapat menyerap semua hal yang berkaitan dengan kehidupan sehari-harinya, seperti membaca, berhitung, maupun menulis.

Membaca permulaan adalah sebagai suatu proses yang dilakukan serta dipergunakan oleh pembaca untuk memperoleh pesan yang hendak disampaikan oleh penulis melalui media kata-kata atau bahasa tulis. Membaca permulaan mencakup: (1) membaca merupakan suatu proses,

${ }^{16}$ Al-Hafidz Ahsin W, Bimbingan Praktis Menghafal Al-Qur'an, (Yogyakarta: Pustaka Pelajar, 2006), hal.23.

${ }^{17}$ Muazar Habibi, Analisis Kebutuhan Anak usia Dini.(Yogyakarta: Depublish,2018), hal.76. 
(2) membaca adalah strategis, dan (3) membaca merupakan interaktif. ${ }^{18}$

Membaca permulaan pada hakikatnya adalah suatu aktivitas untuk menangkap informasi bacaan baik yang tersurat maupun yang tersirat dalam bentuk pemahaman bacaan secara literal, inferensial, evaluatif, dan kreatif dengan memanfaatkan pengalaman pembaca.

Jadi, membaca permulaan adalah membaca yang diajarkan secara terpadu, yang menitik beratkan pada pengenalan hurur dan kata, menghubungkannya dengan bunyi.

\section{Tahapan Membaca Permulaan}

Dalam proses membaca permulaan Anak Usia Dini. Ada tahapan pengajaran yang dilakukan oleh guru sebagai petunjuk dalam pengajaran. Perkembangan membaca permulaan anak-anak dapat dikatagorikan ke dalam lima tahap, yaitu sebagai beriku:

a. Tahap Magic

Pada tahap ini belajar tentang guna buku, mulai berpikir bahwa buku adalah sesuatu yang penting. Anak melihat- lihat buku, membawa-bawa buku, dan sering memiliki buku favorit.

b. Tahap Konsep Diri

Anak melihat diri sendiri sebagai pembaca, mulai terlihat dalam kegiatan "pura-pura membaca", mengambil makna dari gambar, membahasakan buku walaupun tidak cocok dengan teks yang ada di dalamnya.

c. Tahap Membaca Antara

Anak-anak memiliki kesadaran terhadap bahan cetak (print). Mereka mungkin memilih kata yang sudah dikenal, mencatat katakata yang berkaitan dengan dirinya, dapat membaca ulang cerita yang telah ditulis, dapat membaca puisi. Anak-anak mungkin mempercayai setiap silabel sebagai kata dan dapat menjadi frustasi ketika mencoba mencocokkan bunyi dan tulisan. Pada tahap ini, anak mulai mengenali alfabet.

d. Tahap Lepas Landas

Pada tahap ini anak-anak mulai menggunakan tiga sistem tanda/ciri

${ }^{18}$ Ahmad Susanto, Perkembangan Anak Usia Dini. (Jakarta: Prenada Media Group, 2011), hal.88.

Jurnal Pelangi Jurnal pemikiran dan penelitian pendidkan Islam anak Usia Dini 
yakni grafofonik, semantik, dan sintaksis. Mereka mulai bergairah membaca, mulai mengenal huruf dari konteks, memperhatikan lingkungan huruf cetak dan membaca apa pun di sekitarnya, seperti tulisan pada kemasan, tanda-tanda. Resiko bahasa dari tiap tahap ini adalah jika anak diberikan terlalu banyak perhatian pada setiap huruf.

e. Tahap Independen

Anak dapat membaca buku yang tidak dikenal secara mandiri, mengkonstruksikan makna dari huruf dan dari pengalaman sebelumnya dan isyarat penulis. Anak-anak dapat membuat perkiraan tentang materi bacaan. Materi berhubungan langsung dengan pengalaman yang paling mudah untuk dibaca, tetapi anakanak dapat memahami struktur dan genre yang dikenal, serta materi ekpositoris yang umum. ${ }^{19}$

Sedangkan menurut yang lain, tahapan dan proses membaca permulaan pada anak usia dini, antara lain;

1. Tahap kesadaran terhadap tulisan.

Pada tahap ini, anak mulai belajar menggunakan buku dan menyadari bahwa buku ini penting, melihat-lihat buku dan membalik-balik buku kadang-kadang anak membawa buku kemana-mana tempat kesenangannya.

2. Tahap membaca gambar.

Anak mulai memandang dirinya sebagai pembaca.

3. Tahap pengenalan bacaan.

Anak mulai mengerti bunyi huruf, arti kata dan anak mulai mengenal tanda atau symbol yang ada disekitarnya.

4. Tahap membaca lancer. ${ }^{20}$

Sudah dapat membaca lancar buku-buku yang berhubungan dengan kehidupan sehari-hari. ${ }^{21}$

Pengajaran membaca permulaan lebih ditekankan pada pengembangan kemampuan dasar membaca. Siswa dituntut untuk dapat menyuarakan huruf, suku kata, kata dan kalimat yang disajikan

${ }^{19}$ Ana Widyastuti, Kita Jitu Anak Gemar Memabaca Tulis, (Jakarta:PT Gramedia, 2017), hal.2.

${ }^{20} \mathrm{Ibid}, \ldots . .$. ..hal.4-6

${ }^{21}$ Derry Iswidharmanjaya, Bila Anak Usia Dini Bersekolah, (Jakarta: PT Elex Media Komputindo,2008), hal.54. 
dalam bentuk tulisan ke dalam bentuk lisan.

Berdasarkan beberapa penjelasan di atas tentang tahap membaca dari dua pendapat diatas sebenarnya hampir sama sehingga dapat disimpulkan, bahwa ada beberapa tahap membaca yang dapat distimulus agar anak dapat membaca yaitu tahap magic, tahap konsep diri, tahap pembaca antara, tahap lepas landas, tahap independen.

\section{Proses Membaca Permulaan}

Mengajar membaca harus memperhatikan aspek-aspek perkembangan anak. Pengajaran membaca diarahkan pada aspek-aspek: a. Pengembangan aspek sosial anak, yaitu: kemampuan bekerja sama, percaya diri, pengendalan diri, kestabilan emosi, dan rasa tanggung jawab.

b. Pengembangan fisik, yaitu pengaturan gerak motorik, koordinasi gerak mata dan tangan.

c. Perkembangan kognitif, yaitu membedakan bunyi, huruf, menghubungkan kata dan makna. ${ }^{22}$

Pengajaran membaca yang paling baik adalah pengajaran yang didasarkan pada kebutuhan anak dan mempertimbangkan apa yang telah dikuasai anak. Kegiatan yang dilakukan dalam pengajaran membaca antara lain sebagai berikut:

a. Peningkatan Ucapan

Pada kegiatan ini difokuskan pada peningkatan kemampuan anak mengucapkan bunyi-bunyi bahasa. Anak yang mengalami kesulitan dalam mengucapkan bunyi-bunyi tertentu anak menghadapi kesulitan dalam membaca. Bunyi-bunyi yang sulit diucapkan anak bunyi tersebut perlu dilatih secara terpisah.

b. Kesadaran Fonemik ( Bunyi)

Pada kegiatan ini difokuskan untuk menyadarkan anak bahwa kata dibentuk oleh fonem atau bunyi yang membedakan makna.

c. Hubungan antara Bunyi-huruf

Syarat utama untuk dapat membaca adalah mengetahui tentang hubungan bunyi-bunyi. Anak yang mengalami kesulitan dalam hal hubungan bunyi- huruf maka pengajaranya secara terpisah. 
d. Membedakan Bunyi-bunyi

Membedakan bunyi-bunyi merupakan kemampuan yang penting dalam pemerolehan bahasa, khususnya membaca.

e. Kemampuan Mengingat

Kemampuan mengingat yang dimaksud lebih mengarah pada kemampuan untuk menilai apakah dua bunyi atau lebih itu sama atau berbeda.

f. Membedakan huruf

Membedakan huruf adalah kemampuan membedakan huruf-huruf (lambang bunyi). Jika anak masih kesulitan membedakan huruf, maka anak belum siap membaca.

g. Orientasi dari Kiri ke Kanan

Anak perlu disadarkan bahwa kegiatan membaca dalam bahasa indonesia menggunakan sistem dari kiri kekanan. Kesadaran ini perlu ditanamkan pada anak "kidal".

h. Keterampilan Pemahaman

Anak yang mengalami hambatan dalam perkembangan kognitifnya juga mengalami kesulitan dalam membaca, sebab membaca pada dasarnya merupakan kegiatan berpikir. Perlu disadari bahwa kegiatan pemahaman tidak harus menunggu sampai lancar membaca.

i. Penguasaan Kosa Kata

Pengenalan kata merupakan proses yang melibatkan kemampuan mengidentifikasi simbol tulisan, mengucapkan dan menghubungkan dengan makna. ${ }^{23}$

Proses membaca permulaan yang dimaksud adalah membiasakan anak membaca sejak dini, dengan materi yang bermakna serta terpusat pada pengetahuan sehari-hari sehingga anak lebih mudah untuk memahaminya, kegiatan membaca yang dilakukan sesuai dengan kebutuhan dan minat yang sesuai dengan karateristik anak, maka anak lebih mudah untuk dibimbing untuk kegiatan membaca yang selanjutnya.

${ }^{23}$ Rusman, Model-Model Pembelajaran:Mengembangkan Profesionalisme Guru, (Jakarta: PT. Rajagrafindo Persada, 2010), hal.16.

Muazar Habibi, Analisis Kebutuhan hal.65. 


\section{Metode atau Panduan Mengajar Membaca Permulaan Anak Usia Dini}

\section{a. Panduan mengajar membaca permulaan Anak Usia Dini}

Dalam meningkatkan kemampuan membaca permulaan anak usia dini, guru dituntut untuk memliki cara atau metode yanmg tepat sesuai dengan kebutuhan belajar anak. Adapun Panduan untuk mengajarkan membaca untuk anak usia dini:

1) Ajak anak ke dalam perpustakaan, biarkan anak memilih buku yang disukai oleh anak.

2) Ketika mengajarkan membaca, beri kata-kata yang masih belum dikenal anak.

3) Ajak anak melakukan permainan kata seperti tebak kata dan permainan merangkai kata.

4) Kondisikan anak membaca bersama teman-teman sebayanya sebagai sarana untuk menumbuhkan motivasi dalam diri anak.

5) Berikan catatan-catatan tempelkan pada tempat yang sering dikunjungi anak dalam rumah.

6) Berikan hadiah ketika anak berprestasi.

7) Batasi waktu anak untuk bermai game dan menonton televisi. ${ }^{24}$

Materi yang diajarkan dalam membaca permulaan adalah:

1) Lafal dan intonasi kata dan kalimat sederhana.

2) Huruf-huruf yang banyak digunakan dalam kata dan kalimat sederhana yang sudah dikenal siswa (huruf-huruf diperkenalkan secara bertahap sampai dengan 14 huruf).

3) Kata-kata baru yang bermakna (menggunakan huruf-huruf yang sudah dikenal),misalnya: toko, ubi, boneka, mata, tamu.

4) Lafal dan intonasi kata yang sudah dikenal dan kata baru (huruf yangdiperkenalkan 10 sampai 20 huruf). ${ }^{25}$

Dari penjelasan di atas dapat disimpulkan bahwa pengajaran membaca harus didasarkan pada kebutuhan dan mempertimbangkan kemampuan anak agar pembelajaran membaca dapat terlaksana dengan apa yang diharapkan.

\footnotetext{
${ }^{24}$ Rusman, Model-Model Pembelajaran:Mengembangkan Profesionalisme Guru, (Jakarta: PT. Rajagrafindo Persada, 2010), hal.16.

${ }^{25}$ Muazar Habibi, Analisis Kebutuhan.... hal.65.
}

Jurnal Pelang̉i Jurnal pemikiran dan penelitian pendidkan Islam anak Usia Dini 


\section{b. Menggunakan media gambar}

Kegiatan belajar untuk anak usia dini sangat erat kaitannya dengan media pempelajaran. Media pembelajaran sangat penting karena dalam mengajarkan anak akan sesuatu anak harus konkrit atau nyata. Media yang digunakan tidak asal-asalan harus disesuaikan dengan kebutuhan dan tingkat perkembangannya. Media atau sarana pendukung pembelajaran untuk pembalajaran membaca salah satunnya adalah kartu bergambar. Media kartu bergambar merupakan salah satu sarana pembelajaran yang termasuk dalam jenis media pembelajaran visual yang dapat dijadikan media pembelajaran dalam kegiatan belajar membaca permulaan.

Media gambar binatang adalah kartu yang berisi kata-kata dan gambar yang digunakan untuk menambah kosakata anak dalam pembelajaran bahasa. Kelebihan kartu bergambar yaitu dapat merealisasikan pemikiran yang abstrak dalam bentuk gambar, lebih mudah ditemukan, dapat digunakan untuk semua jenjang pendidikan, dapat menumbuhkan minat anak. Sedangkan kekurangannya adalah ukuran tebatas sehingga terkadang gambar kurang jelas dilihat dan untuk anak-anak usia dini lebih suka menggunakan kartu bergambar untuk bermain. ${ }^{26}$

Dalam pembelajaran membaca permulaan, ada beberapa metode yang dapat digunakan seperti hal-hal berikut;

1. Metode abjad dan metode bunyi

Kedua model tersebut sering menggunakan kata lepas. Metode abjad adalah metode pengajaran yang memperkenalkan huruf yang harus dilafalkan dengan lafalan menurut bunyi dalam abjad tersebut. Huruf yang telah dilafalkan kemudian dirangkaikan menjadi suku kata, suku kata menjadi kata, dan kata menjadi kalimat. Pada metode ini pengucapan hurufhuruf sesuai dengan abjad a, b, c, d, dst. Contoh: Ini ayam, i-n-i a-y-am, i-ni a-yam, ini ayam

2. Metode bunyi adalah metode pembelajaran membaca permulaan dengan menyuarakan huruf konsonan dengan bantuan bunyi vokal.

\footnotetext{
${ }^{26}$ Metasari Nursanti, "Pengembangan Pembelajaran Media Kartu Pintar Bola Basket Dalam Tehnik Dasar Bola Basket Untuk Anak usia dini, Jurnal, Universitas Negeri Yogyakarta, No.11 Vol.43, 2015), hal.22.
} 
Pada metode ini mengucapkan huruf-huruf sesuai dengan bunyinya a, beh, ceh, deh, dst. Contoh, ini harimau: i-n-i h-a-r-i-m-a-u, i-ni hari-ma-u, ini harimau

3. Metode kupas rangkai suku kata dan metode kata lembaga penerapannya menggunakan cara mengurai dan merangkaikan.

4. Metode menggunakan media gambar binatang. Contoh: guru memlih binatang yang dikenali sama anak usia dini, lalu ditempel dan menggunting nama-nama binatang kemudian ditempel pada binatang tersebut. Seperti pada gambar dibawah ini. ${ }^{27}$

Seperti contoh pada gambar dibawah ini.
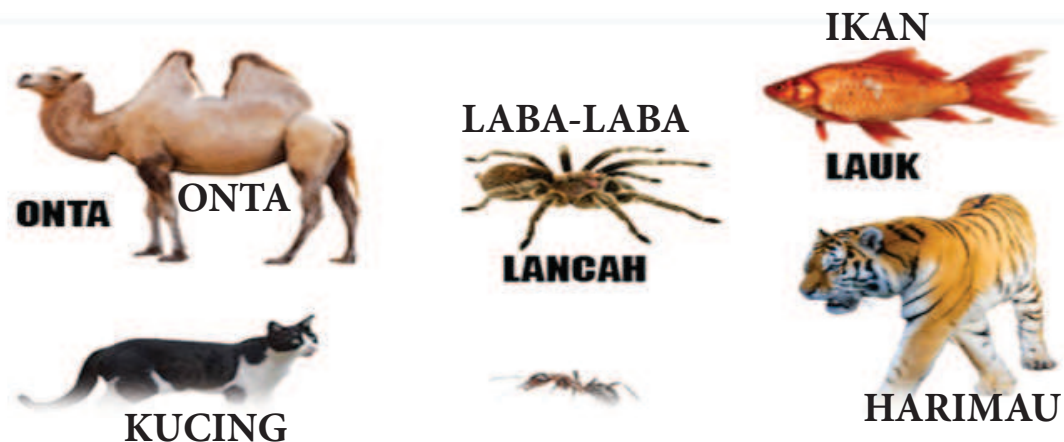

\section{MEDIA MEMBACA PERMULAAN}

\section{Media Gambar}

Gambar adalah segala sesuatu yang diwujudkan secara visual kedalam bentuk dua dimensi sebagai curahan ataupun pikiran yang bermacam-macam seperti lukisan, potret, slide, atrip, opaque proyektor. ${ }^{28}$

Jadi, media gambar adalah alat untuk membantu proses belajar mengajar sehingga menimbulkan daya tarik tersendiri untuk peserta didik dan dapat membantu menstimulasi daya penglihatan anak terhadap objek.

27Itadz, Memilih, Menyusun dan Menyajikan, Cerita untuk Anak Usia Dini, (Yogyakarta:Tiara Wacana, 2008), hal.25.

28Armida, Penerepan Media Gambar Dalam Meningkatkan Berbahasa Anak Pada TK Mekarjaya Bengkunat Belimbing Pesisir Barat, Skripsi, (Fakultas Tarbiayah IAIN Lampung, 2016), hal.19. 


\section{Fungsi, Tujuan dan Manfaat Menggunakan Media Gambar Dalam Membaca Permulaan}

a. Fungsi Menggunakan Media Gambar

Pemanfaatan media gambar ada dalam metode mengajar sebagai salah satu upaya untuk mempertinggi proses interaksi antar guru dengan anak dilingkungan belajar. Oleh sebab itu, fungsi utama media gambar adalah sebagai alat bantu dalam proses mengajar atau proses pembelajaran yang dapat digunakan oleh guru.

b. Tujuan Menggunakan Media Gambar

Adapun tujuan menggunakan media gambar, antara lain;

1. Untuk menjelaskan suatu masalah agar masalah tersebut mudah dipahami oleh anak misal gambar dibuat secara rinci dengan di bawah gambar diberi tulisan.

2. Sebagai sarana pengajaran yang berbentuk gambar yang mengandung makna situasi, keadaan, peristiwa dan benda.

3. Sebagai sumber belajar, fungsi semantik, fungsi psikologis dan fungsi sosio-kultural. ${ }^{29}$

c. Manfaat

Adapun manfaat penggunaan media gambar, antara lain

1. dapat menerjemahkan ide/gagasan yang sifatnya abstrak menjadi lebih konkrit.

2. Untuk menarik perhatian murid

3. Untuk memperjelas menyampaikan pesan

4. Untuk mengaktifkan dan mengefektifkan kegiatan belajar murid.

5. Dapat digunakan pada setiap tahap kegiatan pendidikan dan semua tema. ${ }^{30}$

Jadi dapat disimpulkan bahwa manfaat penggunaan media gambar, antara lain; (1) pelontar stimulus belajar, (2) penarik mint belajar, (3 contoh perilaku belajar, (4) member kondisi eksternal, (5) menuntun cara berfikir, (6) memasukkan alih ilmu, (7) menilai prestasi dan (8) pemberi umpan balik.

${ }^{29}$ Ayu, Riana Gusti, Penerapan Media Gambar Dalam Meningkatkan Kemampuan Berbicara di TK Athfal Lampung, Skripsi, Fakultas Tarbiyah UIN Lampung, 2018), hal. 26.

${ }^{30} \mathrm{Ibid}_{\text {,.......hal.27. }}$ 
Dari kedua pendapat diatas dapat disimpulkan bahwa manfaat menggunakan media gambar adalah untuk menarik minat belajar peserta didik dan juga sebagai sarana untuk mentransfer ilmu dari pemberi materi ke penerima materi.

\section{KONSEP ANAK USIA DINI}

\section{Pengertian Anak Usia Dini (AUD)}

Anak usia dini adalah anak yang berada pada rentan usia 0-6 tahun. Anak usia dini merupakan golden age, masa keemasan seseorang manusia, yang tepat sekali untuk menamkan nilai-nilai kebajikan, baik yang bersumber dari ajaran agama, adat, budaya, tradisi, etika masyarakat (moralitas) dan sebagainya. ${ }^{31}$

Berdasarkan uraian diatas, dapat disimpulkan bahwa anak usia dini adalah anak usia 0-8 tahun yang sedang mengalami pertumbuhan dan perkembangan yang sangat pesat, serta memiliki karakteristik unik, egosentris, imajinatif, memiliki rasa ingin tahu yang besar, dan daya konsentrasi pendek.

\section{Karakteristik Anak Usia Dini}

Anak usia dini memiliki karakteristik yang berbeda dengan orang dewasa, karena anak usia dini tumbuh dan berkembang dengan banyak cara dan berbeda. Anak usia dini memiliki karakteristik, antara lain:

a) Bersifat egosentris naïf

b) Mempunyai relasi sosial dengan benda- benda dan manusia yang sifatnya sederhana dan primitif.

c) Ada kesatuan jasmani dan rohani yang hampir-hampir tidak terpisahkan sebagai satu totalitas.

d) Sikap hidup yang fisiognomis, yaitu anak secara langsung membertikan atribut atau sifat lahiriah atau materiel terhadap setiap penghayatanya. ${ }^{32}$

${ }^{31}$ Abdul Azis, Meletakkan Fondasi Usia Emas Anak Indonesia, Pola Pembeljaran PAUD Berkarakter, (Klaten: Cempaka Putih, 2016), hal.12.

${ }^{32}$ Mansur, Pendidikan AnakUsia Dinidalam Islam, Cetakan Ke-V,(PustakaPelajar:Yogyakarta,2014), hal.28.

Jurnal Pelangi Jurnal pemikiran dan penelitian pendidkan Islam anak Usia Dini 
Berdasarkan karakteristik yang telah disampaikan maka dapat diketahui bahwa karakteristik anak usia dini merupakan masa sensitif bagi anak untuk belajar bahasa. Dengan koordinasi gerakan yang baik anak mampu menggerakan mata-tangan untuk mewujudkan imajinasinya kedalam bentuk gambar, sehingga penggunaan gambar karya anak dapat membantu meningkatkan kemampuan bicara anak. ${ }^{33}$

\section{Aspek-aspek Perkembangan Anak Usia Dini}

\section{a. Perkembangan Fisik dan Motorik}

Perkembangan fisik/motorik akan mempengaruhi kehidupan anak baik secara langsung ataupun tidak langsung. Secara langsung, perkembangan fisik akan menentukan kemampuan dalam bergerak. Secara tidak langsung, pertumbuhan dan perkembangan fisik akan mempengaruhi bagaimana anak memandang dirinya sendiri dan orang lain.

Perkembangan fisik meliputi perkembangan badan, otot kasar dan otot halus, yang selanjutnya lebih disebut dengan motorik kasar dan motorik halus. Perkembangan motorik kasar berhubungan dengan gerakan dasar yang terkoordinasi dengan otak seperti berlari, berjalan, melompat, memukul dan menarik. Sedangkan motorik halus berfungsi untuk melakukan gerakan yang lebih spesifik seperti menulis, melipat, menggunting, mengancingkan baju dan mengikat tali sepatu. ${ }^{34}$

\section{b. Perkembangan Kognitif}

Mansur menyatakan bahwa, perkembangan kognitif menggambarkan bagaimana pikiran anak berkembang dan berfungsi sehingga dapat berpikir. ${ }^{35}$

Perkembangan kognitif merupakan proses mental yang mencakup pemahaman tentang dunia, penemuan pengetahuan, pembuatan perbandingan, berfikir dan mengerti. Proses mental yang dimaksud adalah proses pengolahan informasi yang menjangkau kegiatan kognisi, intelegensi, belajar, pemecahan masalah dan pembentukan konsep.

${ }^{33}$ Susanto, Pendidikan Anak Usia Dini dan Perkembangannya menurut Islam, (Pustaka Ofsait:Bandung, 2012), hal.22.

${ }^{34} \mathrm{Ibid}, \ldots . . .$. hal.29.

${ }^{35}$ Ibid,.......hal.33. 
Anak usia 5-6 tahun berada pada tahap praoperasional. Pada tahap ini anak mulai menunjukan proses berfikir yang jelas. Anak mulai mengenali beberapa simbol dan tanda termasuk bahasa dan gambar. Penguasaan bahasa anak sudah sistematis, anak dapat melakukan permainan simbolis. Namun, pada tahap ini anak masih egosentris. Santrock, menyatakan bahwa, pada usia ini anak-anak mulai menggunakan desain-desain acak untuk menggambar orang, rumah, mobil, awan dan sebagainya.

\section{c. Perkembangan Bahasa}

Penguasaan bahasa anak berkembang menurut hukum alami, yaitu mengikuti bakat, kodrat dan ritme yang alami. Menurut Susanto, perkembangan bahasa anak berjalan sesuai jadwal biologisnya. ${ }^{36} \mathrm{Hal}$ ini dapat digunakan sebagai dasar mengapa anak pada umur tertentu sudah dapat berbicara, sedangkan pada umur tertentu belum dapat berbicara.

Perkembangan bahasa tidaklah ditentukan pada umur, namun mengarah pada perkembangan motoriknya. Namun perkembang tersebut sangat dipengaruhi oleh lingkungan. Bahasa anak akan muncul dan berkembang melalui berbagai situasi interaksi sosial dengan orang dewasa yang berada disekitar lingkungan hidupnya.

Bahasa memiliki peranan yang sangat penting dalam kehidupan sehari-hari. Susanto menyatakan bahwa, peranan bahasa bagi anak usia dini diantaranya sebagai sarana untuk berfikir, sarana untuk mendengarkan, sarana untuk berbicara dan sarana agar anak mampu membaca dan menulis. Melalui bahasa seseorang dapat menyampaikan keinginan dan pendapatnya kepada orang lain. ${ }^{37}$

Jadi, kemampuan bahasa berkaitan erat dengan kemampuan kognitif anak, walaupun mulanya bahasa dan pikiran merupakan dua aspek yang berbeda. Namun sejalan dengan perkembangan kognitif anak, bahasa menjadi ungkapan dari pikiran.

\section{d. Perkembangan Emosi dan Perkembangan Sosial}

Emosi merupakan perasaan atau afeksi yang melibatkan perpaduan

\footnotetext{
${ }^{36}$ Susanto, Perkembangan Anak Usia Dini, Pengantar Dalam Berbagai Aspeknya, (Kencana Prenada Media Group, 2012), hal.36.

${ }^{37}$ Ibid,......hal.26.
}

Jurnal Pelang̉i Jurnal pemikiran dan penelitian pendidkan Islam anak Usia Dini 
antara gejolak fisiologis dan gelaja perilaku yang terlihat. ${ }^{38}$ Perkembangan emosi memainkan peranan yang penting dalam kehidupan terutama dalam hal penyesuaian pribadi dan sosial anak dengan lingkungan. ${ }^{39}$

Adapun dampak perkembangan emosi adalah sebagai berikut: 1) emosi menambah rasa nikmat bagi pengalaman sehari-hari, 2) emosi menyiapkan tubuh untuk melakukan tindakan,3) emosi merupakan suatu bentuk komunikasi, 4) emosi mengganggu aktifitas mental, dan 6) reaksi emosi yang diulang-ulang akan menjadi kebiasaan. ${ }^{40}$ Pendidikan perlu dilihat sebagai suatu proses yang berterusan,berkembang,dan serentak dengan perkembangan individu seorang anak yang mempelajari apa saja yang ada di lingkungannya. Dengan kemahiran yang diperolehnya anak akan mengaplikasikannya dalam konteks yang bermacam-macam dalam hidup kesehariannya di saat itu ataupun sebagai persiapan untuk kehidupannya dimasa yang akan datang.

\section{METODELOGI PENELITIAN}

Adapun jenis penelitian dalam skripsi ini adalah penelitian kualitatif deskriptif. Penelitian kualitatif adalah jenis penelitian yang menghasilkan penemuan-penemuan yang tidak dapat dicapai dengan menggunakan prosedur-prosedur statistik atau cara-cara lain dari kuantifikasi (pengukuran). ${ }^{41}$

Jenis penelitian kualitatif deskriptif adalah metode untuk menyelidiki obyek yang tidak dapat diukur dengan angka-angka ataupun ukuran lain yang bersifat eksak. Metode penelitian kualitatif deskriptif adalah suatu metode dalam meneliti status sekelompok manusia, suatu objek, suatu set kondisi, suatu sistem pemikiran ataupun suatu kelas peristiwa pada masa sekarang. ${ }^{42}$ Sumber data dalam penelitian ini terbagi menjadi dua yaitu: Data Primer. Data primernya seperti: guru, siswa. Sedangkan

${ }^{38}$ Mansur, Pendidikan Anak Usia Dini dalam Islam. hal.28.

${ }^{39}$ Ibid,......hal.29.

${ }^{40}$ Susanto, Perkembangan Anak Usia Dini, Pengantar dalam berbagai. hal.55.

${ }^{41}$ Sujarweni, Metode Penelitian Bisinis dan Ekonomi, (Yogyakarta:Pustaka Baru Press, 2015), hal.21

${ }^{42}$ Creswel, Research Design, Kualitatif, Kuantitatif, Mixed, (Pustaka Pelajar, Yogyakarta, 2016), hal.44. 
Data Sekunder berupa buku-buku dan jurnal. ${ }^{43}$

Teknik pengumpulan Data. Adapun teknik yang digunakan dalam pengumpulan data ini adalah: (1) Metode Observasi. Observasi atau pengamatan berarti dengan menggunakan indera penglihatan. ${ }^{44}$ Observasi digunakan untuk melakukan pengamatan terhadap keadaan pembelajaran pengenalan membaca permulaan anak usia dini (AUD) di TK Ma;aruf Desa Lanci Jaya Kab. Dompu. (2) Metode wawancara. Wawancara atau interview adalah usaha mengumpulkan informasi dengan mengajukan pertanyaan secara lisan, untuk dijawab secara lisan pula. Ciri utama dari interview adalah kontak langsung dengan tatapan muka antara si pencari informasi dengan informasi. ${ }^{45}$ (3) Metode dokumentasi. Metode dokumentasi adalah cara mengumpulkan data dengan mencatat data yang sudah ada. Dokumen itu dibagi atas dokumen pribadi dan dokumen resmi. Dokumen pribadi berisikan catatan pribadi sedangkan dokumen resmi berisikan catatan formal. ${ }^{46}$ (4) Instrumen Penelitian. Instrumen penelitian adalah alat atau fasilitas yang digunakan untuk mempermudah peneliti dalam mengumpulkan data, sehingga data diperoleh jelas, sitematis, lebih cermat, lengkap serta prosesnya lebih mudah. Adapun instrumen penelitian yang digunakan adalah pedoman wawancara dan pedoman dokumentasi.

Tehnik Analisi Data. Adapun tahap-tahap analisis data yang digunakan dalam penelitian ini adalah: (1) Reduksi Data. Dalam reduksi data ada beberapa yang harus dilakukan antara lain: (a) Identifikasi satuan (unit) yaitu mengidentifikasi sebagian kecil yang dikemukakan dalam data yang memiliki makna yang terkait dengan fokus dan masalah dalam penelitian. (b) Memuat koding yaitu memberi kode pada setiap satuan agar tetap dapat ditelusuri satuannya, yang berasal dari sumber yang diperoleh. Koding adalah klasifikasi jawaban dari responden kedalam ketegori-kategori. ${ }^{47}$ (c) Kategorisasi. Kategorisasi adalah upaya memilih setiap satuan keadaan bagian-bagian yang memiliki kesamaan dan setiap kategori diberi nama yang disebut dengan label. (d) Sintesisasi. Sintesisasi adalah upaya mencari kaitan antara satu kategori dengan kategori lainnya diberi nama atau label. ${ }^{48}$

\footnotetext{
${ }^{43}$ Ahmad Usman, Mari Belajar Meneliti, ( Yogyakarta: Genta Press, 2008), hal.252.

${ }^{44} \mathrm{Ibid}$, ,......hal.118.

${ }^{45}$ Maleong., "Metodologi Penelitian Kualitatif", (Bandung: Remaja Rosada Karya, 2002), hal.135.

${ }^{46} \mathrm{Ibid}, . . . .$. hal119.

${ }^{47}$ Ahmad Usman, Mari Belajar.........hal.118.

${ }^{48} \mathrm{Ibid}, . . . .$. hal.201.
}

Jurnal Pelang̉i Jurnal pemikiran dan penelitian pendidkan Islam anak Usia Dini 
Pengujian Kredibilitas Data. Keabsahan data bertujuan untuk membuktikan bahwa apa yang diamati oleh peneliti sesuai dengan apa yang sesungguhnya ada dalam keabsahan. Dalam hal pencapaian rincian kredibilitas data peneliti harus mennggunakan cara yang sesuai dengan fokus peneliti. (1) Mengadakan Membercheck. Membercheck adalah proses pengecekan data yang diperoleh peneliti kepada pemberi data, dengan tujuan untuk mengetahui seberapa jauh data yang diperoleh yang sesuai dengan apa yang diberikan oleh pemberi data. Membercheck dapat dilakukan setelah periode pengumpulan data selesai atau setelah mendapat suatu temuan atau kesimpulan. ${ }^{49}(2)$ Cross Check. Dalam penelitin ini peneliti menggunakan metoode Cross Check, metode Cross Check ini dilakukan dengan mengecek data yang berasl dari wawancara dengan dokumentasi. Selanjutnya Cross Check dilakukan untuk mengecek kembali kebenaran data yang berasal dari wawancara dengan dokumentaasi, membandingkan antara hasil wawancara subjek penelitian yang satu dengan subjek penelitian lainnya, dan antara dokumen yang satu dengan yang lainnya. (3) Triangulasi. Triangulasi adalah teknik pemeriksaan keabsahan data yang memanfaatkan sesuatu yang lain diluar data untuk keperluan pengecekan atau sebagai pembanding terhadap data itu. Dengan membedakan 3 (tiga) macam triangulasi sebagai tekhnik pemeriksaan yang memanfaatkan pengunaan sumber metode, penyidik dan teori. Adapun langkah-langkah dalam kegiatan ini adalah:

a. Mencek kembali data yang ada

b. Menganalisis data-data yang ada

c. Menyimpulkan data-data yang ada. ${ }^{50}$

\section{HASIL PENELITIAN}

\section{Upaya Guru Dalam Pengenalan Membaca Permulaan Anak Usia Dini (AUD) dengan Menggunakan Media Gambar Binatang Pada Kelompok B di TK Ma'aruf Desa Lanci Jaya Kab. Dompu}

Pembelajaran pendidikan TK bertujuan membantu meletakkan dasar kearah perkembangan sikap pengetahuan, keterampilan, daya

\footnotetext{
${ }^{49} \mathrm{Ibid}, \ldots . .$. hal.131.

${ }^{50}$ Creswel, Research Design, Kualitatif, Kuantitatif, Mixed,............hal.34.
} 
cipta dan menyiapkan anak untuk memasuki pendidikan dasar dengan mengembangkan nilai-nilai agama (moral), fisik motorik, kognitif, bahasa, sosial emosi, dan seni. Stimulasi yang diberikan oleh guru merupakan hal yang sangat penting dalam pengenalan membaca permulaan anak usia dini. Dalam pengenalan membaca permulaan, dibutuhkan stimulasi. Stimulasi tersebut sangat membantu anak usia dini dalam pengenalan membaca.

Hasil wawancara dengan Bapak Ma'aruf, menyatakan bahwa upaya guru dalam pengenalan membaca anak usia dini di TK Ma'aruf dilakukan dengan menggunakan perminan gambar binatang;

"Guru sebagai pengajar biasanya dirumah akan memikirkan tema apa yang cocok untuk diterapakan pada saat proses belajar mengajar. Upaya yang dilakukan oleh guru adalah dengan menggunakan media gambar binatang. Hal yang utama dilakukan adalah menentukan tema pembelajaran dan memilih gambar binatang yang sesuai dengan kebutuhan belajar anak usia dini. Di TK Ma;aruf pengenalan membaca permulaan dilakukan dengan menggunakan gambar media binatang, seperti gambar kuda, kambing, sapi, kerbau, dan kucing". ${ }^{51}$

Penggunaan media gambar binatang sangat membantu proses pengenalan membaca anak usia dini di TK Ma'aruf sehingga penggunaan media gambar binatang tersebut tetap digunakan dalam proses pembelajaran dari tahu ke tahun.

Sedangkan menurut Ibu Erma, S.Pd menyatakan bahwa upaya guru dalam pengenalan membaca permulaan anak usia dini di TKMa' aruf adalah dilakukan dengan menggunakan media gambar binatang dan metode yang lain yang digunakan adalah menggunakan poster yang bertuliskan huruf abjad (A, B, C dan seterusnya). Berikut hasil wawancaranya"

“Upaya guru dalam pengenalan membaca permulaan anak usia dini di TK Ma'ruf dilakukan dengan menggunakan media gambar binatang, seperti media gambar binatang kuda, sapi, kerbau, harimau, laba-laba, kucing, dan singa. Dalam pengenalan membaca permulaan tersebut, guru menyediakan terlebih dahulu gambar binatang dirumah dan di print lalu waktu di sekolah ditempelkan di papan tulis, kemudian guru menanyakan ke siswa-siswi tentang gambar tersebut serta dibaca satu persatu dan siswa mengikutinya". ${ }^{52}$

${ }^{51}$ Ma'aruf, Wawancara, Dompu, 22 Agustus 2019.

${ }^{52}$ Erma, Wawancara, Bima, 1 Oktober 2019.

Jurnal Pelang̉i Jurnal pemikiran dan penelitian pendidkan Islam anak Usia Dini 
Gambar sebagai media pendidikan dapat membuat anak untuk melatih dan mempertajam imajinasi anak, maka akan semakin berkembang sudut pandang anak dalam membahasakan gambar. Gambar seri adalah gambar yang urutanya secara seri yang bisa disesuaikan atau diurutkan sesuai dengan urutan jalan ceritanya. Seperti tergambar dalam ungkapan Syamsah, S.Pd, dibawah ini;

"Adapun istrumen yang digunakan oleh guru dalam meningkatkan kemampuan membaca permulaan adalah menggunakan gambar. Setelah siswa dapat membaca tulisan dibawah gambar, sedikit demi sedikit gambar dikurangi sehingga ahirnya mereka dapat membaca tanpa dibantu oleh gambar lagi. Salah satu gambar yang digunakan adalah gambar media binatang seperti kuda, kerbau, laba-laba dan harimau. Dalam kegiatan ini yang digunakan kartu-kartu kalimat serta papan slip atau flanel." 53

Anak membutuhkan metode yang menarik dalam belajar membaca. Salah satu media yang digunakan adalah media gambar binatang. Metode ini dapat dinyatakan berhasil apabila menggunakan media yang efektif. Dengan menggunakan media gambar binatang dan penyediaan poster yang berisikan huruf abjad mampu meningkatkan kemampuan membaca permulaan anak usia dini di TK Ma'aruf.

Berdasarkan hasil wawancara di atas dapat disimpulkan bahwa upaya guru dalam pengenalan membaca permulaan pada anak usia dini dilakukan dengan menggunakan media gambar binatang, seperti gambar binatang kuda, kerbau, sapi, laba-laba serta harimau.

\section{Kendala yang dihadapi oleh Guru Dalam Pengenalan Membaca Permulaan Anak Usia Dini (AUD) dengan Menggunakan Media Gambar Binatang Kelompok B di TK Ma'aruf Desa Lanci Jaya Kecamatan Manggelewa Kab. Dompu}

Melihat rendahnya minat membaca permulaan anak usia dini, maka salah satu cara untuk memudahkan anak belajar lancar membaca adalah dengan menerapkan metode pembelajaran yang sesuai dengan kebutuhan anak. Anak membutuhkan metode yang menarik dalam belajar membaca. Salah satu media yang dugunakan adalah media gambar binatang.

\footnotetext{
53Syamah, Wawancara, Bima, 1 Oktober 2019.
} 
Metode ini dapat dinyatakan berhasil apabila menggunakan media yang efektif. Meskipun telah banyak upaya guru dalam mengenalkan membaca permulaan terdapat beberapa kendala. Seperti yang dikatan sama Bapak Ma'aruf, S.Pd selaku kepala sekolah, dibawah ini;

"Memang harus diakui bahwa ada kendala yang dihadapi oleh kami dalam proses pengenalan membaca permulaan, salah satunya adalah anak kurang mengenali huruf. Ketidakmampuan anak dalam mengenal huruf-huruf alfabetis seringkali dijumpai oleh kami. Ketidakmampuan anak dalam mengenali huruf, sulit membedakan huruf besar/ kapital dan huruf kecil serta kebanyakan anak belum mengenal dan menghafal huruf abjad atau angka. Kendala yang dihadapi oleh guru dilatarbelakangi oleh murid itu sendiri." 54

Media gambar binatang sebenarnya sangat penting karena menjadi alat bantu dalam pengenalan membaca permulaan bagi anak usia dini. Dengan menggunakan media gambar anak dapat menyusun kalimat sederhana. Namun terdapat kendala yang dihadapi oleh guru TK Ma'aruf, seperti yang katakan sama Ibu Erma, S.Pd, dibawah ini;

"Kendala yang paling besar yang dihadapi oleh kami dalam pengenalan membaca permulaan adalah banyak anak yang tidak mengenali kata, kurang menguasai kata, kurang dorongan orang tua sehingga mempengaruhi pada anak." 55

Kendala yang dihadapi oleh anak usia dini tersebut adalah kendala universal. Dalam artian semua pernah dirasakan oleh guru sebagai pengajar di TK. Seperti yang disampaikan oleh Ibu Syamsah dalam wawancara dibahawah ini;

"Salah satu kendalanya adalah ketidakmampuan anak dalam mengenal huruf-huruf alfabet. Ketidakmampuan anak dalam mengenali huruf,dan kebanyakan anak belum mengenal dan menghafal huruf abjad atau angka sehingga bisa dikatakan kurang lancar membaca" 56

Kendala yang sangat urgen dihadapi oleh Guru TK Ma'ruf adalah masih banyak anak usia dini yang belum mengenal huruf alfabetis atau angka sehingga memperlambat anak dalam proses pengenalan membaca permulaanya.

\footnotetext{
${ }^{54}$ Ma'aruf, Wawancara, Dompu, 22 Agustus 2019.

${ }^{55}$ Erma, Wawancara, Bima, 1 Oktober 2019.

${ }^{56}$ Syamah, Wawancara, Bima, 1 Oktober 2019.
}

Jurnal Pelang̉i Jurnal pemikiran dan penelitian pendidkan Islam anak Usia Dini 
Jadi berdasarkan hasil wawancara di atas, dapat disimpulkan bahwa kendala yang dihadapi oleh guru dalam pengenalan membaca sebagai berikut; (1) kurang mengenali huruf dan sulit membedakan huruf besar atau kapital dan huruf kecil, (2) kebanyakan anak belum mengenal dan menghafal huruf abjad atau angka, (3) kurang dorongan orangtua.

\section{DAFTAR PUSTAKA}

Al-Hafidz Ahsin W, 2006, Bimbingan Praktis Menghafal Al-Qur'an, Yogyakarta: Pustaka Pelajar.

Armida, 2016, Penerepan Media Gambar Dalam Meningkatkan Berbahasa Anak Pada TK Mekarjaya Bengkunat Belimbing Pesisir Barat, Skripsi, Fakultas Tarbiayah IAIN Lampung.

Ayu, Riana Gusti, 2018, Penerapan Media Gambar Dalam Meningkatkan

Kemampuan Berbicara di TK Athfal Lampung, Skripsi, Fakultas Tarbiyah UIN Lampung.

Azis Abdul, 2016, Meletakkan Fondasi Usia Emas Anak Indonesia, Pola

Pembeljaran PAUD Berkarakter, Klaten: Cempaka Putih.

Creswel, 2016, Research Design, Kualitatif, Kuantitatif, Mixed, Yogyakarta: Pustaka Pelajar.

Creswel, Research Design, Kualitatif, Kuantitatif, Mixed,

Derry Iswidharmanjaya, 2008, Bila Anak Usia Dini Bersekolah, Jakarta:

PT Elex Media Komputindo.

Fakhruddin, 2010, Sukses Menjadi Guru TK-PAUD, Tips, Strategi, dan Panduan Pengembangan Praktisnya, Jogjakarta: Being.

Habibi Muazar, 2018, Analisis Kebutuhan Anak usia Dini, Yogyakarta: Depublish.

Hamalik, 2010, Proses Belajar Mengajar, Jakarta: PT Bumi Aksara:

Itadz, 2008, Memilih, Menyusun dan Menyajikan, Cerita untuk Anak Usia Dini, Yogyakarta: Tiara Wacana.

Majid dan Puspitasari, 2006, Pendidikan Agama Islam Berbasis Kompeten, Bandung: PT Rosdakarya.

Maleong, 2002, Metodologi Penelitian Kualitatif, Bandung: Remaja Rosada Karya.

Mansur, 2014, Pendidikan Anak Usia Dini dalam Islam, Cetakan Ke-V, Yogyakarta: Pustaka Pelajar. 
Mansur, 2014, Pendidikan Anak Usia Dini dalam Islam, Cetakan Ke-V, Pustaka Pelajar: Yogyakarta.

Mansur, 2015, Pendidikan Anak Usia Dini dalam Islam, Bandung: Remaja Rosada Karya.

Muazar Habibi, Analisis Kebutuhan

Nursanti Metasari, 2015, Pengembangan Pembelajaran Media Kartu Pintar Bola Basket Dalam Tehnik Dasar Bola Basket Untuk Anak usia dini, Jurnal, Universitas Negeri Yogyakarta, No.11 Vol.43.

Rahim Farida, 2011, Pengajaran Membaca di Sekolah Dasar, Jakarta: Bumi Aksara.

Rusman, 2010, Model-Model Pembelajaran:Mengembangkan Profesionalisme Guru, Jakarta: PT. Rajagrafindo Persada.

Solehan, 2008, Pendidikan Bahasa Indonesia di SD, Jakarta: Universitas Terbuka.

Sujarweni, 2015, Metode Penelitian Bisinis dan Ekonomi, Yogyakarta:Pustaka Baru Press.

Susanto Ahmad, 2011, Perkembangan Anak Usia Dini, Jakarta: Prenada Media Group.

Susanto, 2012, Pendidikan Anak Usia Dini dan Perkembangannya menurut Islam, Pustaka Ofsait:Bandung.

Susanto, 2012, Perkembangan Anak Usia Dini, Pengantar Dalam Berbagai Aspeknya, Kencana Prenada Media Group.

Susanto, Perkembangan Anak Usia Dini, Pengantar dalam berbagai, Bandung: Remaja Rosada Karya.

Suyadi, 2011, Manajemen Pendidikan Anak Usia Dini, Pustaka Pelajar: Yogyakarta.

Syah Muhibin, 2015, Psikologi Pendidikan Dengan Pendekatan Baru, Bandung:PT Remaja Rodakarya.

Syamah, Wawancara, Bima, 1 Oktober 2019.

Usman Ahmad, Mari Belajar meneliti, Yogyakarta: Genta Press, 2008.

Usman Ahmad, Mari Belajar Meneliti, 2008, Yogyakarta: Genta Press.

Usman Basyirudin dan Asnawir, 2002, Media Pembelajaran, Jakarta, Ciputat Pers.

Widyastuti Ana, 2017, Kita Jitu Anak Gemar Memabaca Tulis, Jakarta:PT Gramedia. 